\title{
COMPRESSIVE PROPERTIES OF AUXETIC STRUCTURES PRODUCED WITH DIRECT 3D PRINTING
}

\author{
STISKANJE STRUKTUR MATERIALOV Z NEGATIVNIM \\ POISSONOVIM RAZMERJEM, PROIZVEDENIH Z NEPOSREDNIM \\ TRIDIMENZIONALNIM TISKANJEM
}

\author{
Petr Koudelka ${ }^{1,2}$, Ondřej Jiroušek ${ }^{2}$, Tomáš Fíla ${ }^{1,2}$, Tomáš Doktor ${ }^{1,2}$ \\ ${ }^{1}$ Institute of Theoretical and Applied Mechanics, Academy of Sciences of the Czech Republic, Prosecká 76, 190 00 Prague, Czech Republic \\ ${ }^{2}$ Czech Technical University in Prague, Faculty of Transportation Sciences, Konviktská 20, 11000 Prague 1, Czech Republic \\ jirousek@fd.cvut.cz
}

Prejem rokopisa - received: 2014-08-19; sprejem za objavo - accepted for publication: 2015-04-24

doi:10.17222/mit.2014.204

\begin{abstract}
In the presented paper, three types of auxetic structures were produced with direct 3D printing and their compressive mechanical properties were tested. Samples were prepared from acrylic material suitable for high-resolution direct printing. Three different structures exhibiting in-plane and volumetric negative strain-dependent Poisson's ratio were selected for the analysis: two-dimensional missing-rib cut, two-dimensional inverted (re-entrant) honeycomb and three-dimensional inverted (re-entrant) honeycomb. The samples were subjected to quasi-static compression, from which stress-strain relationships were established. For a proper strain evaluation, digital-image correlation was applied to measure full-field displacements on the sample surfaces. From the displacement fields, true strain/true stress curves were derived for each sample. Furthermore, for each structure a three-dimensional FE model was developed using beam elements and subjected to identical loading conditions. Then, experimentally obtained stress-strain relationships were compared with numerically obtained results. For all the tested auxetic structures, the compressive behaviour was predicted well by the FE models. This demonstrates that parametric FE models can be used to tune the design parameters of the structures with a negative Poisson's ratio to optimize their overall properties.

Keywords: auxetics, cellular materials, quasi-static testing, finite-element method
\end{abstract}

$\mathrm{V}$ prispevku so predstavljene tri vrste struktur materialov z negativnim Poissonovim razmerjem, ki so proizvedene $\mathrm{z}$ neposrednim tridimenzionelnim tiskanjem. Preizkušene so bile njihove mehanske lastnosti pri stiskanju. Vzorci so bili pripravljeni iz akrilnih materialov, ki so primerni za visoko resolucijsko neposredno tiskanje. Za analizo so bile izbrane tri različne strukture, ki prikazujejo negativno odvisno Poissonovo razmerje v ravnini in v prostoru: dvodimenzionalni prerez $\mathrm{z}$ manjkajočim rebrom, dvodimenzionalni obrnjeni (navznoter usmerjeni) vzorec satovja in tridimenzionalni obrnjeni (navznoter usmerjeni) vzorec satovja. Vzorci so bili izpostavljeni kvazi-statičnem stiskanju pri katerem smo ugotavljali razmerja sile raztezek. Za primerno oceno sile obremenitve je bila uporabljena metoda korelacije digitalne slike in s tem izmerjeni odmiki na površini vzorcev. Glede na te odmike so bile za vsak vzorec izpeljane dejanske obremenitvene krivulje. Nadalje je bil za vsako strukturo izdelan tridimenzionalni FE model, z uporabo matematičnega modela podpornih struktur in izpostavljen identičnim pogojem obremenitve. Nato smo primerjali eksperimentalno pridobljena razmerja med silo in obremenitvijo, $\mathrm{z}$ računsko pridobljenimi rezultati. S pomočjo primerjalnih diagramov sile in raztezka lahko ugotovimo, da FE modeli dobro napovedujejo obnašanje pri stiskanju vseh preizkušenih struktur z negativnim Poissonovim razmerjem. To prikazuje možnost uporabe parametričnih FE modelov za prilagoditev zasnovnih parametrov struktur z negativnim Poissonovim razmerjem za optimiziranje njihovih splošnih lastnosti.

Ključne besede: materiali z negativnim Poissonovim razmerjem, celični materiali, kvazi-statično preizkušanje, metoda končnih elementov

\section{INTRODUCTION}

Porous solids (i.e., open- or closed-cell foams) are materials suitable for applications requiring a significant mass reduction and a simultaneous high-impact energy absorption. This is provided by the foams' low specific weight and thus high specific stiffness. However, for certain applications (including blast protection), it may be necessary to use materials with a relatively high compressive strength, which disqualifies the usage of most foam types including metallic foams. ${ }^{1}$ To improve the strength and energy absorption capacity without increasing the mass of constructional elements, a new type of material had to be found. One of the possible approaches to dealing with the absorption of enormous amounts of deformation energy during blast and impact loading of structures is to produce a highly optimized porous structure, taking advantage of the negative Poisson's ratio of its skeleton. ${ }^{2}$

Historically, a structure with a negative Poisson's ratio was first reported for single crystals of iron pyrites and was attributed to crystal twinning. ${ }^{3}$ This initial finding was followed only by isolated reports in the 1970s and 1980s showing that negative Poisson's ratio is a rather unique phenomenon among natural constructs. First artificially prepared auxetic polymeric foam was reported in 1987 by Lakes ${ }^{4}$ when commercially available foam was modified in a process involving $30 \%$ volumetric compression and heating of the samples to the polymer's softening temperature followed by cooling 
whilst remaining under compression. Although research of the microstructures prepared with various similar techniques from the existing materials continued, the investigation of the auxetic-based materials capable of deformation-energy absorption closely followed the advances in additive manufacturing (i.e., selective laser sintering, direct 3D printing, etc.).

The reported auxetic topologies are mostly based on re-entrant, chiral, double-arrow-head and rotating-rigid unit cells..$^{5-8}$ Deformation behaviour (both elastic and plastic) of such a porous construct is determined by concurrent effects of intrinsic behaviour of the material used for the scaffold production, cell topology and connectivity. To optimize its microstructure to suit the intended application and to achieve a stable negative Poisson's ratio up to high strains, a control over the pore structure is required. Here, the usage of additive manufacturing is favourable as all the intended geometrical characteristics can be attained deterministically, satisfying the need for a high mechanical integrity of the construct during deformation and the need for precise tuning of the overall stiffness and plastic properties.

Several unit-cell models having a well-defined Poisson's function (strain-dependent Poisson's ratio) described analytically have already been proposed. ${ }^{9-12}$ In this study, samples of three microstructures utilizing both the in-plane and volumetric negative Poisson's ratio were produced with direct $3 \mathrm{D}$ printing to evaluate their compressive-deformation behaviour in both elastic and plastic regime up to the densification. Deformation of the microstructures during quasi-static uni-axial compression tests was optically observed using a CCD camera and the digital-image-correlation (DIC) method was used for the strain evaluation. Moreover, mechanical behaviour of the structures was investigated numerically with virtual experiments (i.e., simulations of the compression tests) using finite element (FE) method. The simulations were carried out using identical loading and boundary conditions and the numerically obtained stress-strain curves were compared to the experimental ones to test the proposed material model for the base material.
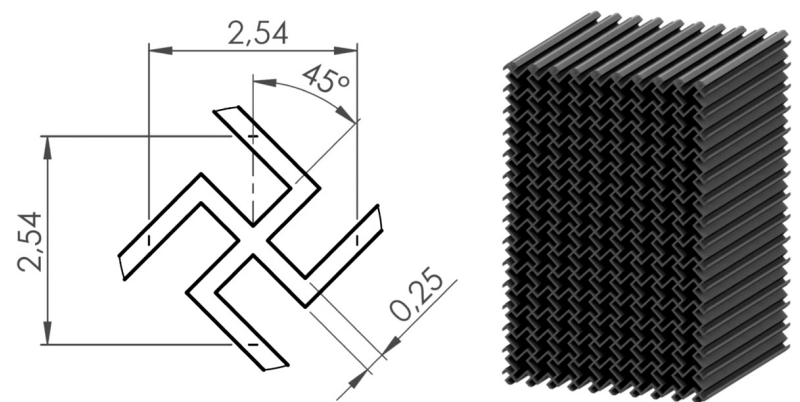

Figure 1: Missing-rib-cut structure: a) unit cell geometry and b) visualisation of the whole sample

Slika 1: Struktura prereza z manjkajočim rebrom: a) geometrija celice in b) vizualizacija celotnega vzorca

\section{EXPERIMENTAL PART}

\subsection{Specimen geometry}

In this study, three different types of unit-cell geometry were used: a) two-dimensional missing-rib cut, b) two-dimensional inverted (re-entrant) honeycomb and c) three-dimensional inverted honeycomb. These unit cells were arranged so that predictable (determinate) in-plane or volumetric negative strain-dependent Poisson's ratio was achieved in the cases of two-dimensional and threedimensional geometries, respectively. Constructs of two-dimensional geometries were generated by extruding a planar (single-layer) arrangement of the unit cells whereas a three-dimensional construct was created by copying a fully three-dimensional unit cell along all the spatial directions.

The missing-rib-cut model was formed by removing selected ribs (the elements forming a unit cell) from the periodical arrangement of squares and by rotating the construct by $45^{\circ}$ to the direction of loading. ${ }^{13}$ Auxetic behaviour of such a construct depends on the unit-cell dimensions and the angles between individual ribs. The geometry of a unit cell with the dimensions used in this work and a visualisation of the specimen are depicted in Figure 1. The dimensions of the produced construct were $25.05 \mathrm{~mm} \times 25.40 \mathrm{~mm} \times 37.75 \mathrm{~mm}$ (width, depth, height), the overall porosity was $72.8 \%$ and the construct consisted of $10 \times 15$ cells.

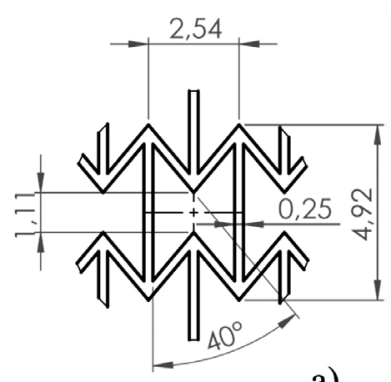

a)
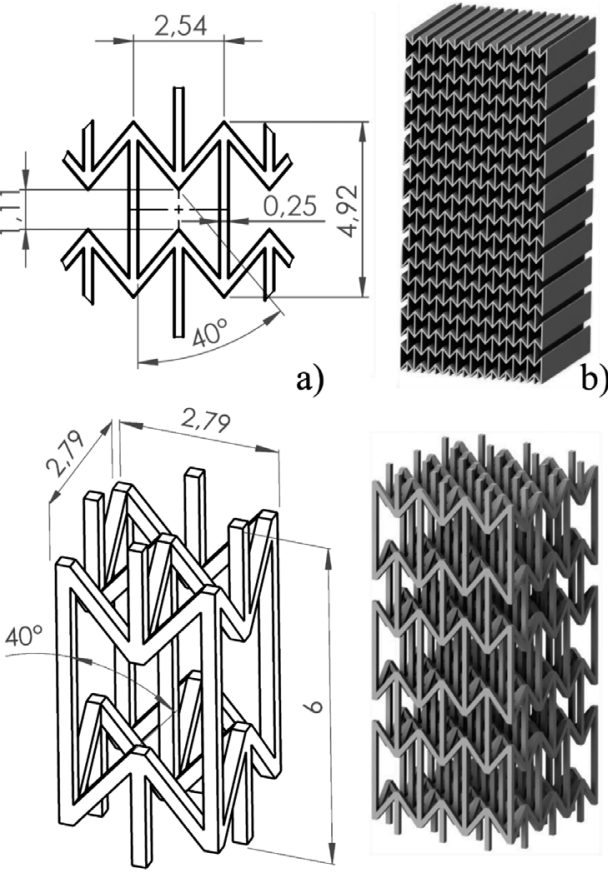

c) d)
Figure 2: a) 2D re-entrant structure - unit cell geometry, b) visualisation of the whole sample, c) 3D re-entrant structure - unit cell geometry and d) visualisation of the whole sample

Slika 2: a) dvodimenzionalna navznoter usmerjena struktura - geometrija celice, b) vizualizacija celotnega vzorca, c) tridimenzionalna navznoter usmerjena struktura - geometrija celice in d) vizualizacija celotnega vzorca 
The re-entrant mesh is generated by changing the four side angles between the ribs in a six-sided honeycomb. ${ }^{14}$ The magnitude of Poisson's ratio at a given strain is here primarily given with the length ratio of individual ribs forming the unit cell. Both two-dimensional and three-dimensional arrangements of the re-entrant unit cells together with visualisations of the specimens are shown in Figure 2. Dimensions of the produced two-dimensional construct were $25.65 \mathrm{~mm} \times$ $25.40 \mathrm{~mm} \times 58.89 \mathrm{~mm}$ (width, depth, height), the overall porosity was $73.2 \%$ and the construct consisted of $10 \times$ 15 cells; dimensions of the produced three-dimensional construct were $7.87 \mathrm{~mm} \times 7.87 \mathrm{~mm} \times 18 \mathrm{~mm}$ (width, depth, height), the overall porosity was $91.7 \%$ and the construct consisted of three cells in every spatial direction.

\subsection{Specimen preparation}

The specimens were manufactured from VisiJet EX200 (3D Systems, USA) UV curable acrylic material suitable for high-resolution 3D printing. The physical properties of the material are summarised in Table $\mathbf{1 .}$

For the specimen production, a Pro Jet HD3000 (3D Systems, USA) 3D printer in the high-definition mode was used. The manufacturing principle is based on a multi-jet modelling technology where a special printing head covers the whole working area of $198 \mathrm{~mm} \times 185$ $\mathrm{mm} \times 203 \mathrm{~mm}$ and builds up the model by adding individual layers of the produced geometry. Simultaneously, while modelling the material, a supporting wax material is automatically added to the construct to enable a production of very complex geometries.

Thanks to its low melting point (approximately $55-65{ }^{\circ} \mathrm{C}$ ) all the supporting material can be simply removed from the products by heating it in a water bath to approximately $80{ }^{\circ} \mathrm{C}$ without a potential mechanical damage to the products. A SolidWorks (Dassault Systèmes SolidWorks Corp., France) parametric modeller was used to design the sample geometry that was exported to the STL format for the 3D printing. The final samples were produced with a resolution of $(328 \times 328 \times$ 606) DPI ( $x, y, z$ direction) with a layer thickness of $0.036 \mathrm{~mm}$. In this mode, the accuracy of printing was approximately $0.025-0.05 \mathrm{~mm}$ and the production process took approximately $11 \mathrm{~h}$.

Table 1: Properties of the VisiJet EX200 material Tabela 1: Lastnosti materiala VisiJet EX200

\begin{tabular}{|c|c|c|}
\hline Mass density & 1.02 & $\mathrm{~g} / \mathrm{cm}^{3}$ \\
\hline Tensile modulus & 1.283 & $\mathrm{GPa}$ \\
\hline Tensile strength & 42.4 & $\mathrm{MPa}$ \\
\hline Flexural modulus & 1.159 & $\mathrm{GPa}$ \\
\hline Glass transition temp. & 52.5 & ${ }^{\circ} \mathrm{C}$ \\
\hline
\end{tabular}

\subsection{Experimental set-up}

The experiments were carried out using an in-house designed loading set-up based on a novel modular compression/tension loading device suitable for both optical and X-ray observation of deformation processes ${ }^{15}$ equipped with a U9b force transducer (HBM, Germany) with a nominal force capacity of $2 \mathrm{kN}$. The signal from the load cell was read out using an OM502T (Orbit Merret, CZ) load-cell indicator at a sampling rate of 50 $\mathrm{Hz}$.

Imaging was performed using a Manta G504B monochromatic GigE vision camera (AVT, Germany). The camera was equipped with an ICX655 CCD sensor and its maximum frame rate was $9 \mathrm{fps}$, achieved at a resolution of $2452 \mathrm{px} \times 2056 \mathrm{px}$. In order to guarantee a high reliability of the correlation procedure and an accuracy of the computed strains, the camera was equipped with a TCZR 072 bi-telecentric zoom lens (Opto Engineering, Italy). The lens used a steppermotor-controlled zoom revolver to set four different magnifications of the scene in the range of $0.125-1.000$, with a very high image-centre stability, parfocality and no need for a re-calibration after the zooming. The specimens were illuminated using a KL2500 high-power white-light LED source (Schott, Germany).

A detailed description of the loading set-up is shown in Figure 3.

\subsection{Loading procedure and strain measurement}

The loading of the samples was performed as a displacement-driven uniaxial compression. The maximum displacement was set to $8 \mathrm{~mm}$ with a loading rate of $20 \mu \mathrm{m} \mathrm{s}^{-1}$. The positioning of the camera as well as the loading were carried out using in-house developed control software based on the GNU/Linux real-time operating software and LinuxCNC open-source project.

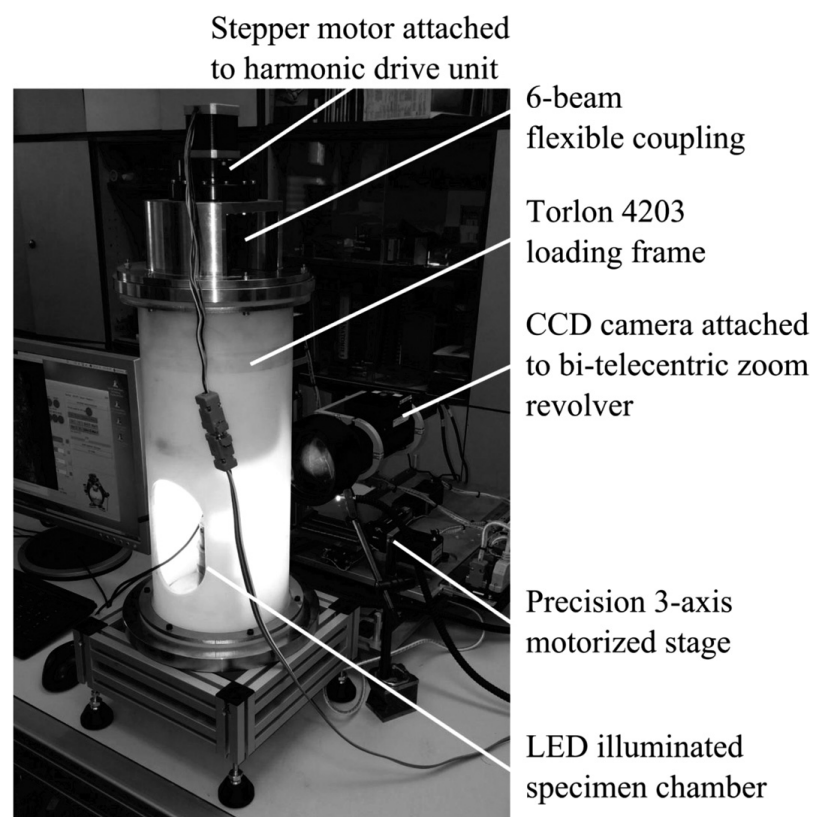

Figure 3: Loading set-up used in the experiments

Slika 3: Postavitev obremenjevanja, ki je bilo uporabljeno pri preizkusih 


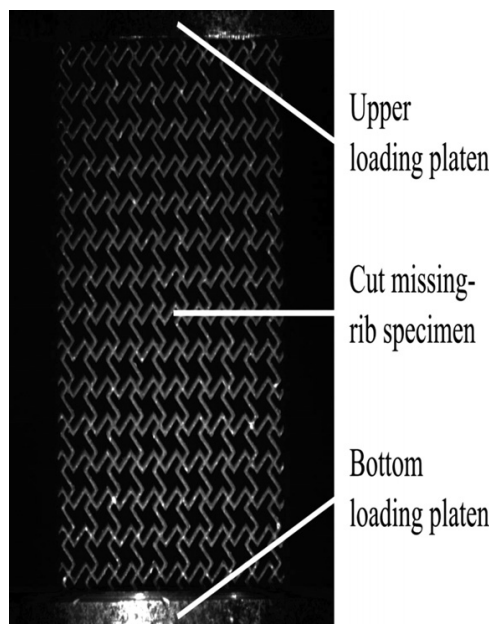

Figure 4: Loading scene captured using a CCD camera during the experiment. Missing-rib specimen with sprayed surface for a DIC strain evaluation.

Slika 4: Trenutek obremenitve, ki je prikazan na CCD kameri med preizkusom. Vzorec z manjkajočim rebrom z napršeno površino za oceno DIC sile obremenitve.

The strains were derived from optically measured displacements using a sequence of the images capturing a deforming sample. Depending on the sample height, 0.125 or 0.25 magnifications were used and the images were captured with the maximum resolution of $2452 \mathrm{px}$ $\times 2056$ px at $2 \mathrm{fps}$, enabling the identification of a sufficient number of points on the stress-strain curve. The acquisition of the projections was controlled with custom-developed software based on the OpenCV library and Python programming language. The observed faces of the specimens were sprayed using granite paint to generate a random pattern for a high reliability of the optical deformation tracking. A selected loading scene is depicted in Figure 4.

\subsection{Stress-strain diagram evaluation}

Displacements were determined from the image sequences using a custom-developed DIC software tool ${ }^{16}$ based on the Lucas-Kanade tracking algorithm ${ }^{17}$ implemented in MATLAB. Two rows of correlation points (markers) perpendicular to the loading direction were selected near the upper and lower edges of the observed surfaces of the specimens. Each marker was in a series of projections tracked by searching for the highest correlation coefficient between two consequent projections.

Engineering-stress $\left(\sigma_{\text {eng }}\right)$ and strain $\left(\varepsilon_{\text {eng }}\right)$ values were determined from the geometrical properties of the tested specimens and optically measured displacements of the markers. Then, true stress $\left(\sigma_{\text {true }}\right)$ and true strain $\left(\varepsilon_{\text {true }}\right)$ were calculated according to Equations (1) and (2):

$$
\begin{gathered}
\sigma_{\text {true }}=\sigma_{\text {eng }}\left(1+\varepsilon_{\text {eng }}\right) \\
\varepsilon_{\text {true }}=\ln \left(1+\varepsilon_{\text {eng }}\right)
\end{gathered}
$$

\section{NUMERICAL PART}

Apart from the experimental methods, analytical and FE models can be used for a description of deformation behaviour of auxetic constructs, allowing a prediction and optimization of the effective mechanical characteristics that facilitate the material design for a specific application.

Most of the analytical models assume small deflections, neglecting the axial deformation of the struts. ${ }^{19}$ Thus, analytical approach can be used to prove the concept of negative Poisson's ratio, optimize the parameters of a structure (e.g., the re-entrant angle, relative density, strut thickness) and maximize the effective parameters of the resulting constructs (i.e., deformation energy per unit volume, yield strength of the structure, compressive strength) according to specific requirements. For instance, using these analytical models, it is possible to express Poisson's ratio $\mu$ of the re-entrant honeycomb structure (Figure 2a) with Equation (3):

$$
\mu=\frac{\sin (90-\theta)\left(L_{2} / L_{1}+\sin (90-\theta)\right)}{\cos ^{2}(90-\theta)}
$$

where $L_{1}$ and $L_{2}$ are the strut lengths and $\theta$ is the strut angle (measured in degrees). The value of resulting Poisson's ratio is negative and its dependency on the magnitude of the angle $\theta$ and the strut length ratio $L_{2} / L_{1}$ corresponds to the observed experimental results. Using the Timoshenko beam theory and the elastic-behaviour assumption, it is possible to express the overall elastic modulus $\mathrm{E}$ and critical-yield compressive force $F_{\mathrm{m}}$ based on the yield strength $\sigma_{\mathrm{y}}$ of the bulk solid material. From the yield compressive force the compressive strength of the structure can be then expressed.

However, these analytical models are effective only when simplifying the assumptions such as the smalldeflection theory and linear elastic-material properties are used. Consequently, these models only give satisfactory results for small deformations and are limited to the calculation of the overall elastic properties or to the estimation of the yield point of a structure.

When large strains with non-linear material properties are to be considered, FE models have to be used instead. Thus, FE models of the tested auxetic structures were developed and subjected to the same loading conditions as during the compression tests. Deformation behaviour of the tested samples under large strains (up to $10 \%$ or $20 \%$ strain) was then compared with the predictions obtained from the numerical models to verify their suitability for a representation of such microarchitectures.

Stress-strain curves were inversely assessed from the FE simulations, i.e., from the reaction forces calculated at the restrained side of a sample. Using such inverse FE simulations, it is relatively easy not only to obtain the stress-strain curves for each considered sample, but also to establish the stresses and strains arising at individual 
struts from the deformation of the structure. Hence, these strains can be easily compared to the values experimentally obtained from the digital-image correlation at the same positions (i.e., individual markers).

For all the considered auxetic constructs, the FE model was created using $3 \mathrm{D}$ beam elements with $6^{\circ}$ of freedom (three translational and three rotational ones) defined at two nodal points. The element is based on Timoshenko beam theory, which includes shear-deformation effects. The material model set in the simulations was elasto-plastic, combining von Mises yield criteria and bilinear isotropic work hardening. The material properties are summarised in Table 2.

Table 2: Material properties used in the FE simulations Tabela 2: Lastnosti materiala uporabljenega pri FE simulaciji

\begin{tabular}{|c|c|c|}
\hline Young's modulus & 1.159 & $\mathrm{GPa}$ \\
\hline Poisson's ratio & 0.2 & - \\
\hline Yield stress & 42.4 & $\mathrm{MPa}$ \\
\hline Hardening tangent modulus & 12.8 & $\mathrm{MPa}$ \\
\hline
\end{tabular}

The loading was prescribed to be done in 100 loading steps, i.e., in each step a $0.1 \%$ or $0.2 \%$ deformation was applied.

In the case of such a large-strain analysis, a highly deformed geometry has an important effect on the strain and, therefore, geometric nonlinearities must be considered. To consider the post-buckling behaviour of the thin beams subjected to a large compression, strain measures have to account for higher-order terms. Thus, in our analyses, material stress-strain properties were input in terms of true stress versus logarithmic strain. In every loading step, reaction forces originating from the
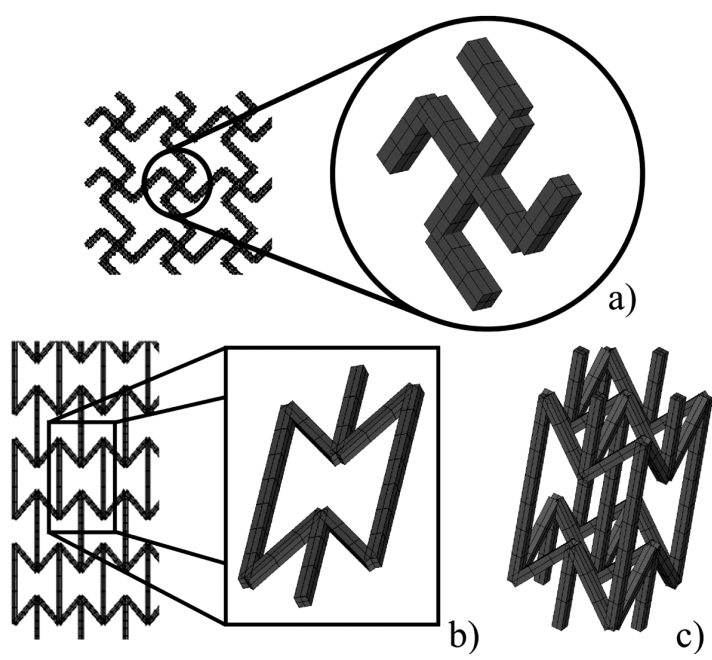

Figure 5: Visualization of FE-model elements used in the numerical simulations: a) missing-rib-structure cut with a detail of the unit cell, b) $2 \mathrm{D}$ re-entrant structure with a detail of the unit cell and c) detail of 3D re-entrant unit cell

Slika 5: Vizualizacija elementov FE modela, ki je bil uporabljen v številčnih simulacijah: a) struktura prereza z manjkajočim rebrom s podrobnostmi enote celice, b) dvodimenzionalna navznoter usmerjena struktura s podrobnostmi enote celice in c) podrobnosti tridimenzionalna navznoter usmerjene enote celice supports were calculated and the true stresses and strains were established using Equations (1) and (2). Visualizations of the FE models for individual constructs can be seen in Figure 5.

\section{RESULTS AND DISCUSSION}

From both the numerical and experimental quasistatic compression tests true stress/true strain diagrams for all three considered auxetic microarchitectures were plotted.

A comparison of the experimental and numerical stress-strain diagrams of the missing-rib-structure cut is depicted in Figure 6.

It can be seen that this type of microstructure exhibits a similar initial compressive behaviour as a typical closed-cell porous solid. The initial linear elastic part is followed by an apparent yield point and a compaction region with a constant stress plateau. These parts are then, at an approximately $17.5 \%$ strain, followed by a region of localized densification due to negative Poisson's ratio of the unit cell and repeated decreases of the stress that can be attributed to the ruptures of beams due to excessive bending. Good correlation of the numerical and experimental results was obtained in terms of stiffness, yield point and plateau stress up to a $20 \%$ strain.

In Figure 7, a comparison of the experimentally and numerically acquired stress-strain diagrams of the twodimensional inverted honeycomb structure is presented.

It is clearly apparent that the microstructure of such a construct exhibits a significantly different deformation behavior than the missing-rib-structure cut. After the initial linear elastic region, a $30 \%$ drop in the stress is followed by cyclic increases and decreases in the stress levels in the specimens with an apparent progressive trend. After a visual inspection of individual projections during the deformation, the occurrence of the cycles can



Figure 6: Comparison of experimentally and numerically obtained stress-strain diagrams of the missing-rib-cut structure

Slika 6: Primerjava eksperimentalno in številčno pridobljenih diagramov sile in raztezka za strukturo prereza z manjkajočim rebrom 


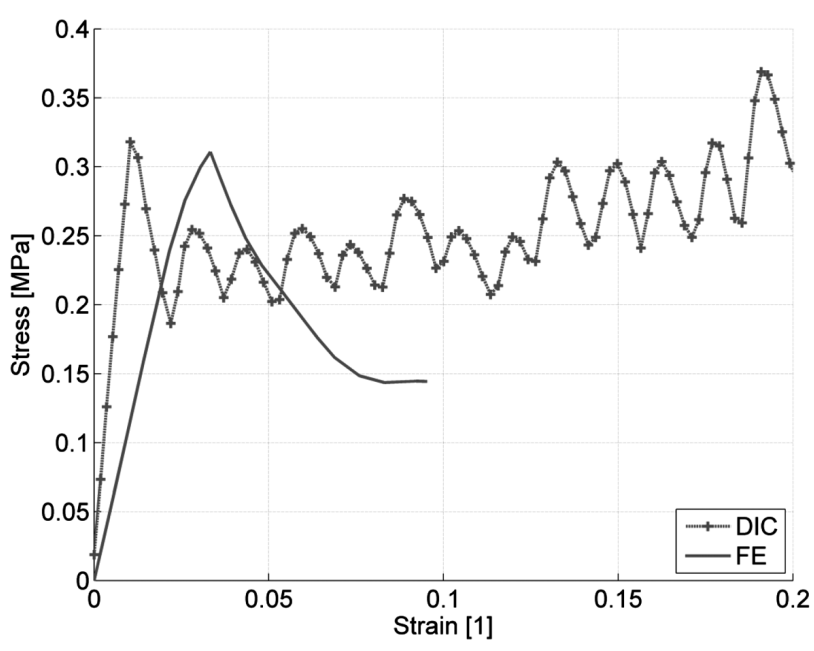

Figure 7: Comparison of experimentally and numerically obtained stress-strain diagrams of the $2 \mathrm{D}$ inverted honeycomb structure Slika 7: Primerjava eksperimentalno in številčno pridobljenih diagramov sile in raztezka za dvodimenzionalno obrnjeno strukturo satovja

be attributed to the collapse of individual layers of the unit cells in the microstructure. For this type of microstructure, FE simulations give a good prediction of the yield point and strain-softening behaviour up to the densification of the individual layers in the microstructure.

A stress-strain diagram showing the experimentally and numerically assessed behavior of the three-dimensional inverted honeycomb structure is shown in Figure 8.

The mechanical response is similar to that of the two-dimensional structure but with a more significant stress drop after the linear elastic region and a lower number of the stress cycles, caused by a $20 \%$ lower overall porosity and a lower number of the cells in the structure. The performance of the FE model is, in this

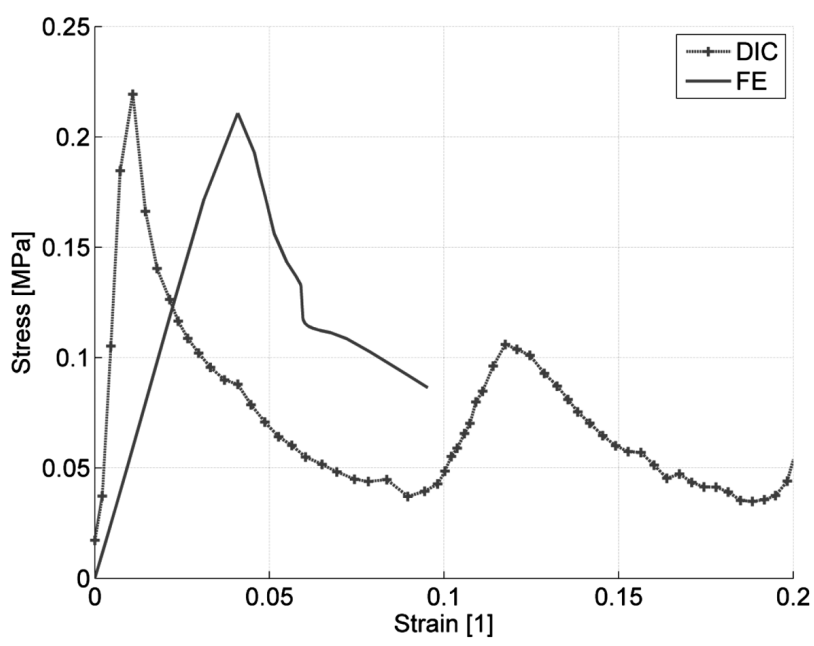

Figure 8: Comparison of experimentally and numerically obtained stress-strain diagrams for the $3 \mathrm{D}$ inverted honeycomb structure

Slika 8: Primerjava eksperimentalno in številčno pridobljenih diagramov sile in raztezka za tridimenzionalno obrnjeno strukturo satovja case, similar to the two-dimensional re-entrant structure with a numerically well-determined yield point and strain-softening characteristics.

Only for the missing-rib cut of the auxetic structure, it was possible to perform the FE analysis up to a $20 \%$ strain. Larger strain values could not be calculated as the elements became extremely distorted, yielding instability and convergence issues of the simulations. Furthermore, to capture the stiffening during the compaction, it would have been necessary to include self-contact between individual struts, which would have significantly increased the complexity and computational costs of the simulations.

The FE simulations of the re-entrant structures predict a smaller overall stiffness, which is apparent from the comparison between the experimental stress-strain curves and the numerically obtained responses. For this reason, a set of three-point-bending experiments was carried out using prismatic beams with rectangular cross-sections that were carefully cut from the printed specimens. Based on the DIC strain evaluation, a bending modulus of approximatly $1.5 \mathrm{GPa}$ was calculated. This value is close to the nominal flexural modulus of $1.2 \mathrm{GPa}$ provided by the manufacturer that was also used in the FE simulations. Thus, the discrepancies between the numerically and experimentally evaluated stiffness might have been caused by properties that were different from the predicted properties of the joints between individual struts, influencing the bending characteristics of individual layers, which formed the principal mode of deformation of the re-entrant structures. Here, a combination of a precise inspection of the geometry and possibly a nanoindentation measurement of the joints should be applied to obtain an accurate material model for the FE simulations.

\section{CONCLUSIONS}

Mechanical behaviour of three different porous microarchitectures exhibiting in-plane and volumetric negative Poisson's ratios was studied both experimentally and numerically. The specimens prepared with high-resolution direct 3D printing were compressively loaded up to the densification regions of their mechanical responses. The true stress/true strain diagrams for the compression were derived from a high-precision force measurement and an optical DIC evaluation of the strain field. Based on the experimental results, numerical FE models of all the considered microarchitectures were developed and their ability to predict mechanical responses of the studied constructs was assessed by comparing the numerically and experimentally obtained stress-strain diagrams. It was found that the deformation response of the missing-rib-cut structure was well captured by the FE model up to a $20 \%$ strain. Simulations of the re-entrant honeycomb structures showed good correlation of the yield point and strain-softening charac- 
teristics up to a $10 \%$ strain, while the calculated stiffness of the models was lower than the stiffness of the measured specimens. Still, the acquired results demonstrate that parametric FE models can be used to tune the design parameters of the structures with negative Poisson's ratio and numerically optimize their overall properties. Therefore, we can conclude that such FE models can be successfully used in material engineering to design highly optimized structures for a given range of strain rates, with maximized strain-deformation energy.

\section{Acknowledgements}

The research was supported by the Czech Science Foundation (research project Nos. P105/12/0824 and 15-15480S) and by RVO: 68378297.

\section{REFERENCES}

${ }^{1}$ Y. Sugimura, J. Meyer, M. Y. He, H. Bart-Smith, J. Grenestedt, A. G. Evans, On the mechanical performance of closed cell foams, Acta Materialia, 45 (1997), 5245-5259

${ }^{2}$ M. Grujicic, J. Galgalikar, J. S. Snipes, R. Yavari, S. Ramaswami, Multi-physics modeling of the fabrication and dynamic performance of all-metal auxetic-hexagonal sandwich-structures, Materials \& Design, 51 (2013), 113-130, doi:10.1016/j.matdes.2013.04.004

${ }^{3}$ W. Voigt, Lehrbuch der Kristallphysik, Teubner, Leipzig 1928

${ }^{4}$ R. Lakes, Foam Structures with a Negative Poisson's Ratio, Science, 235 (1987), 1038-1040, doi:10.1126/science.235.4792.1038

${ }^{5}$ C. Lira, P. Innocenti, F. Scarpa, Transverse elastic shear of auxetic multi re-entrant honeycombs, Composite Structures, 90 (2009) 3, 314-322, doi:10.1016/j.compstruct.2009.03.009

${ }^{6}$ J. Grima, A. Alderson, K. Evans, Auxetic behaviour from rotating rigid units, Physica Status Solidi (b), 242 (2005) 3, 561-575, doi:10.1002/pssb.200460376

${ }^{7}$ D. Prall, R. Lakes, Properties of a chiral honeycomb with a Poisson's ratio of -1 , International Journal of Mechanical Sciences, 39 (1997) 3, 305-314
${ }^{8}$ U. D. Larsen, O. Sigmund, S. Bouwstra, Design and fabrication of compliant micromechanisms and structures with negative Poisson's ratio, Journal of Microelectromechanical Systems, 6 (1997) 2, 99-106

${ }^{9}$ S. Burns, Negative Poisson's Ratio Materials, Science, 238 (1987), 551, doi:10.1126/science.238.4826.551

${ }^{10}$ R. H. Baughman, S. Stafstram, C. Cui, S. O. Dantas, Science, 279 (1998), 1522-1524, doi:10.1126/science.279.5356.1522

${ }^{11}$ K. E. Evans, M. A. Nkansah, I. J. Hutchinson, S. C. Rogers, Molecular network design, Nature, 353 (1991), 124, doi:10.1038/ $353124 \mathrm{a} 0$

${ }^{12}$ L. Rothenburg, A. A. Berlin, R. J. Bathurst, Materials with Negative Poisson's Ratio, Nature, 354 (1991), 470-472

${ }^{13}$ C. W. Smith, J. N. Grima, K. E. Evans, A novel mechanism for generating auxetic behaviour in reticulated foams: missing rib foam mode, Acta Materialia, 48 (2000) 17, 4349-4356, doi:10.1016/ S1359-6454(00)00269-X

${ }^{14}$ I. G. Masters, K. E. Evans, Models for the elastic deformation of honeycombs, Composite Structures, 35 (1996), 403-422, doi:10.1016/S0263-8223(96)00054-2

${ }^{15}$ P. Zlámal, O. Jiroušek, D. Vavř́k, A Novel Compression/Tension Device for Investigation of Trabecular Bone Failure Using RealTime Micro-CT Imaging, 7th Youth Symposium on Experimental Solid Mechanics, 2008, Wroclaw, Poland, 91

${ }^{16}$ I. Jandejsek, J. Valach, D. Vavrik, Optimization and Calibration of Digital Image Correlation Method, Proceedings of Experimental Stress Analysis 2010, edited by P. Smid, (2010), Olomouc, Czech Republic, 121-126

${ }^{17}$ B. D. Lucas, T. Kanade, An Iterative Image Registration Technique with an Application to Stereo Vision, Proceedings of Imaging Understanding Workshop, 1981, Vancouver, Canada, 121-130

${ }^{18}$ T. L. Warren, Negative Poisson's ratio in a transversely isotropic foam structure, Journal of Applied Physics, 67 (1990), 7591-7594, doi:10.1063/1.345826

${ }^{19}$ L. Yang, O. Harrysson, H. West, D. Cormier, Compressive properties of Ti-6Al-4V auxetic mesh structures made by electron beam melting, Acta Materialia, 60 (2012) 8, 3370-3379, doi:10.1016/ j.actamat.2012.03.015 